\title{
LOGISZTIKA A KOMMUNÁLIS HULLADÉKGAZDÁLKODÁSBAN
}

\author{
Budavári Viktória - Gál József
}

\begin{abstract}
Absztrakt: Kettős kapcsolat figyelhető meg a logisztika és a környezetvédelem között. A különleges kezelést igénylö anyagok csomagolása és szállítása hatással van a környezetre, egyrészt a nagy mennyiségü csomagolóanyag hulladék és annak levegőszennyezése miatt. Másrészt a hulladékgazdálkodás logisztikájának célja a környezet védelme. A cél, hogy megakadályozzuk a felhalmozódást a 3R segítségével: csökkentsük, utasítsuk el és hasznosítsuk újra. A jog szabályozza a termelés teljes folyamata alatti teendőket magában foglalva a hulladékgazdálkodást is. Ebben a tanulmányban megvitatjuk a kapcsolatot a logisztika és a hulladékmenedzsment között.
\end{abstract}

Abstract: There is a dual relationship between the logistics and the environment. The effect of packing and transporting is harmful to the environment because of the large amount of package waste and air pollution. On the other hand, the aim of the logistics of waste management is to save the environment. The main aim is to prevent the accumulation of wastes with 3R: reduce, reuse and recycle. Laws regulate the activities during the whole production system involving the waste management, as well. In this paper, the connections between the logistics and the waste management is discussed.

Kulcsszavak: hulladák, logisztika, csomagolás, környezetvédelem

Keywords: waste, logistics. packing, environmental protection

\section{Bevezetés}

A logisztika és a környezet kettős kapcsolata alatt a logisztikai tevékenységek - ezen beluil elsősorban a csomagolás és a szállítás - környezetterhelését, valamint a hulladékkezelési logisztika környezet védelmét célzó tevékenységeit kell érteni (Némonet al., 2006). Utóbbiak közé tartoznak a keletkező hulladék mennyiségének csökkentését, a hulladék környezeti ártalmainak csökkentését - megfelelő (elö)kezeléseket követő újrahasználatát, anyagában történő, vagy energetikai hasznosítását, lerakását - támogató közvetlen és közvetett tevékenységek. A hulladék keletkezésének forrása, helye szerint beszélhetünk települési és ipari / mezőgazdasági hulladékokról. A települési hulladékok komplexebb összetétele miatt nehezebben kezelhetők. A termelési hulladékok összetétele a gazdasági tevékenységtöl függően változik, a hulladék keletkezésének helyére vonatkozó fajlagos mennyisége nagyobb, mint a települési hulladék esetén. Fentiek alapján a hulladékkezelés logisztikai tevékenységei is jelentősen különböznek a gazdaságban keletkezett és a települési hulladékok esetén. Tanulmányunkban a logisztikai tevékenységek és a hulladékgazdálkodás kapcsolatának kettősségéröl lesz szó. A logisztikai tevékenységeken belül a csomagolás és a szállítás környezetterhelése után a termelési és települési hulladékok kezelésére vonatkozó logisztikai hátteret tárgyaljuk. 


\section{Logisztika és hulladékgazdálkodás}

Ebben az esetben olyan folyamatokról van szó, amelyekre nem kerül kellő hangsúly, amelyekről a gyártók nem akartak tudomást sem venni. Két ponton is megjelentek a csomagolóanyagok a termék éltciklusa alatt, mielőtt üzembe helyezték volna (a gyártótól a felhasználóig eljuttatáskor), illetve a használatot követően, mikor már nem funkcionál, azaz kikerül az értéktermelő folyamatból.

\subsection{Logisztika és környezetterhelés}

A logisztikai tevékenységek közül a csomagolás és a szállítás jár a legnagyobb környezetterheléssel. A csomagolóanyagok, csomagoló eszközök miután az ellátási lánc adott szegmensében betöltötték funkciójukat - védelmi, tárolási, szállítási funkció, marketing funkció és informatikai, információt hordozó funkció (Kovács, 2008) - hulladékká válnak (Némon et al., 2006).

\subsubsection{Csomagolás, csomagolási hulladékok kezelése}

A csomagolási hulladékok szelektív összegyüjtésével, kezelésével alkalmassá tehetők újbóli felhasználásra, illetve (elsődlegesen anyagában történő) hasznosításra. Ezzel a környezet terhelését két módon is csökkenthetjük, egyrészt az újrahasználat következtében a hulladék mennyiségének csökkentésével, másrészt a hasznosítás miatt a) a lerakásra kerülö hulladék mennyiségének csökkentésével, valamint b) a keletkező másodnyersanyagok által a primer erőforrások szükségességének csökkentésével. A csomagolási hulladékok kezelése országonként eltérö szabályozáson alapul. Angliában kötelezettséget vállaltak arra, hogy 2000-re az összes csomagolási hulladék felét szelektíven visszagyüjtik és újrahasznosítják. Hollandiában 2000-re mindenfajta csomagolóanyag felhasználásának 10\%-os csökkentését és a csomagolási hulladékok 60\%-ának hasznosítását írták elö, valamint az ország szárazföldi területének korlátai miatt betiltották a hulladéklerakón történö ártalmatlanítást. Svédországban 2000-re a csomagolóanyagok felhasználásának $15 \%$-os csökkentését és az összes csomagolási hulladék 80\%-ának visszanyerését írták elő, valamint betiltották az egyutas (eldobható) csomagolású italok importját. Németországban már 1991-ben elfogadták a csomagolási hulladékok elkerüléséröl szóló törvényt, melynek alapelve, hogy minden használt csomagolást (a rakodólaptól a cukorkás dobozig) hasznosítás céljából vissza kell juttatni a gyártóhoz, importörhöz, forgalmazóhoz. A megosztott felelösség elve alapján a visszavételi kötelezettség, ill. a kötelező betéti díj felszámítása alól mentesülnek azok a gyártók és kereskedők, akik begyüjtő rendszeren keresztül biztosítják a használt csomagolások fogyasztótól történő elszállítását, újrafeldolgozásra alkalmas szétválogatását - azaz a hulladék kezelését más szervezet is elvégezheti. Az osztrák törvényi szabályozás a német rendszerhez hasonló, bár itt a hulladék égetését is engedélyezi a jogszabály. Elöírás szerint 2000re a csomagolószerek $80 \%$-át újra kellett hasznosítani. A fogyasztókat kötelezték a használt csomagolószerek gyüjtésére, tárolására, és azoknak a kibocsátóhoz az újrahasznosításra alkalmas tiszta állapotban történő visszajuttatására. A kibocsátókat kötelezték a csomagolószerek visszavételére és hasznosító vállalatokhoz 
eljuttatására, ugyanakkor a kibocsátók mentesülnek e kötelezettség alól, ha igazolják, hogy megbízásukból a feladatot harmadik személy látja el (Barótfi, 2000). Magyarországon az első hulladékgazdálkodási törvényt 2000-ben fogadták el (2000. évi XLIII. tv.), azaz míg tőlünk nyugatra 2000-re már komoly feltételeket szabtak a csomagolási hulladékok kezelésére vonatkozóan, addig hazánkban ekkor jelent meg az első konkrétan hulladékos témájú törvény. A csomagolási hulladékok kezelésének szabályait a most hatályos jogszabályok alapján a hulladékról szóló 2012. évi CLXXXV. törvény (továbbiakban Hgt.), a csomagolásról és a csomagolási hulladékkal kapcsolatos hulladékgazdálkodási tevékenységekröl szóló 442/2012. (XII. 29.) Kormány rendelet, a környezetvédelmi termékdíjról szóló 2011. évi LXXXV. törvény, valamint a környezetvédelmi termékdíjról szóló 2011. évi LXXXV. törvény végrehajtásáról szóló 343/2011. (XII. 29.) Kormány rendelet tartalmazza. A Hgt. a gyártóra és a forgalmazóra is megfogalmaz a csomagolási hulladék kezelésére vonatkozó kötelezettségeket. Jelenleg hazánkban termékdíj rendszer müködik, mely alapján a gyártó és / vagy a forgalmazó a kötelezöen elöírt hasznosítási arányok betartása mellett pénzügyi hozzájárulás megfizetésével is hozzájárul a környezetszennyezés csökkentéséhez. A célok magasztosak és elöremutatók voltak, a gyakorlatban jelentős lépéseket sikerült tenni megvalósításuk érdekében, viszont mindezek ellenére sem teljesültek maradéktalanul a célként kitüzött 2000 évre.

\subsubsection{A szállítás környezetterhelése}

A szállítási tevékenység környezetterhelése - elsösorban - a levegőszennyezésben és a zajkibocsátásban jelenik meg. Emellett - elsődlegesen a téli jégmentesítés miatt, illetve baleset esetén - talajszennyezésben és a felszíni, illetve felszín alatti vizek szennyezésében is megnyilvánulhat. A szállító jármüvek károsanyag kibocsátása (pl. CO, szénhidrogének, nitrogén-oxidok) okozza a levegöszennyezést. A környezet terhelése függ a szállító jármü müszaki állapotától, illetve a területen történő áthaladási idejétől, sebességétől. A közúti és a vasúti dízelüzemü szállítást összehasonlítva megállapítható, hogy a vasúti áruszállítás tkm-re vetített károsanyag kibocsátása mindössze 25-35\%-a a közúti áruszállítás fajlagos emisszióértékének. Az Európai Unió a közúti közlekedési jármüvekre szigorú előírásokat (pl. Euro 3-as és magasabb kategóriájú jármủvek maximális károsanyag kibocsátása) tesz a környezeti terhelés csökkentése érdekében. Szintén a környezet védelmét szolgálják azok a forgalomszabályozási rendelkezések, melyek az áruszállító jármúvek közlekedését korlátozzák egyes időszakokban. A zajkibocsátás mértékét az útburkolat minősége, a tehergépjármű haladási sebessége (gördülési zaj), és a megválasztott sebességfokozat (motorzaj) befolyásolják. Egy autópályán 80-100 $\mathrm{km} / \mathrm{h}$ sebességgel haladó tehergépkocsi $25 \mathrm{~m}$ távolságban észlelt zajkibocsátása 73$76 \mathrm{~dB}$. Vasúti szállítás zajkibocsátása a vonató jármü és a kerék - sín kölcsönhatásából származik. Ugyanakkor - mivel a szerelvény elhaladási ideje is meghatározó, és a mozdony elhaladási ideje elhanyagolható a teherszerelvények elhaladási idejéhez képest - az utóbbi a meghatározó. Azonos haladási sebesség mellett a 25 m-es távolságból észlelt zajszint a vasúti szerelvény esetén 9-10 dB-lel 
nagyobb, mint a tehergépkocsik zajszintje. Emellett, mivel egy hosszabb vasúti szerelvény zajhatásának ideje hosszabb, mint egy tehergépkocsié, egy vasúti szerelvény zajkibocsátása 8-10 tehergépkocsi zajkibocsátásával egyenértékü (Némonet al., 2006). Tekintettel arra, hogy a vasúti szállítás kötött pályán történik, így annak megvalósítása, csak megfelelő infrastruktúra esetén lehetséges. A fentiek alapján a vasúti szállítás levegőszennyezése kisebb, zajszennyezése nagyobb a közúti fuvarozáshoz képest, ugyanakkor a közúti szállítás a közút hálózat és vasúti hálózat lefedettségének különbségéből adódóan elterjedtebb. Ennek ellenére nagyobb távolságra, nagy mennyiségü áru szállításakor a vasúti fuvarozás kedvezőbb. Magyarországon a folyami áruszállítás belföldi viszonylatban nem jelentős, nemzetközi áruszállításra azonban használják a hazai folyószakaszokat is. A tengeri hajózás, szállítás nem jelentős, hiszen földrajzi adottságainkat tekintve nem rendelkezünk tengerparttal, ugyanakkor több tengeri fuvarozó cég is kiszolgálja a hazai szállítási igényeket. A hajózás környezeti terhelése fajlagosan alacsony, emellett olcsó, azonban csak olyan áruk szállítására használható, melyek a szállítási időre nem érzékenyek. A légi fuvarozás jelentősége az utóbbi időben nő, biżtonságos áruszállítási mód, ugyanakkor drága és a környezetterhelése sem elhanyagolható bár gyakran például utasszállító repülőgépek vagy charter járatok rakterében történik a szállítás, azaz menetrendszerinti járattal, így az áruszállítás fajlagos környezetterhelése nem mérhetö össze a csak áruszállítási céllal indított légi járat fajlagos környezetterhelésével. A nagyobb méretủ áruk, illetve a repülés biztonságát veszélyeztető áruk szállítása nem megoldható, de számos kereskedelmi árucikk fuvarozható. Jellemző az egyes fuvarozási módok kombinált alkalmazása is, mely az egyes elönyöket kihasználva kedvezőbbé teszi az árucikkek eljuttatását a kiindulási helyről a rendeltetési helyre. Hulladékok szállításakor kisebb távolságok esetén a közúti fuvarozás a jellemző, speciális - pl. tömörítős - szállítójármüvek alkalmazásával. Ez elsődlegesen a települési hulladékok begyüjtésére jellemzö. A már begyüjtött, előválogatott és hasznosításra elökészített hulladékok szállítása a célállomás és az előkezelést végző hulladékkezelő vállalkozás telephelyének távolságától, infrastrukturális ellátottságától függően jellemzően közúton, esetleg vasúton, vagy kombinált fuvarozással történik.

\subsection{Hulladékkezelési logisztika}

A bevezetőben már volt szó arról, hogy a különböző anyagok újrahasználata, hasznosítása, másodlagos nyersanyaggá alakítása egyre nagyobb jelentőségüvé válik a környezet védelme, a gazdaság fenntartható fejlödése szempontjából. Ezen tevékenységek elvégzéséhez is szükség van pl. gyửjtésre, tárolásra, szállításra, azaz logisztikára. A hulladékkezelési logisztikán belül az áru (hulladék) áramlási iránya ellentétes a termék előállítási, ellátási lánc áruáramlási irányához képest, ezért nevezik inverz vagy reverz logisztikának (Némon et al., 2006; Kovács et al., 2008). $\mathrm{Az}$ inverz logisztika közvetlen szerepe a különbözö hulladékkezelési tevékenységek (begyüjtés, válogatás, előkezelés, tárolás, szállítás, stb.) megfelelő, gazdaságilag hatékony megoldásának elösegítése. Közvetett feladata a tervezés, szervezés, 
irányítás, azaz a menedzsment szemlélet és módszerei alapján a költséghatékonyság, tendenciák, új technológiák követése, alkalmazása (Mosonyiné, 2008).

\subsubsection{Hulladékkezelési logisztika a gazdasági szférában}

A gazdasági szereplők müködése során elsődlegesen a végzett gazdasági tevékenységtől függő összetételú és mennyiségü hulladék keletkezik. A munkatársak által munkaidőben termelt települési jellegü hulladékok kezelésével itt nem foglalkozunk. Részben azért, mivel kezelésének logisztikai vonatkozásait a következő fejezetben részletezzük; részben azért, mert annak mennyisége elhanyagolható a termelési hulladékok mennyisége mellett. A termelés során a vállalkozások szinte minden lépését jogszabály szabályozza, így amellett, hogy a gazdaságos müködés elérése érdekében önszántukból is mindent el kell követniük a hatékonyság növelésére, ha jogszabálykövető módon akarják a tevékenységüket folytatni, akkor nagyon sok apró mozzanatra kell figyelniük a teljes tevékenységi körükben. Ebbe a beszerzésen, tároláson, termelésen, szállításon, mozgatáson túl a selejtezés, a hulladékok megfelelő kezelése, selejt, illetve félkész termékek visszaforgatása a termelésbe, valamint a logisztika katonai megközelítésének megfelelően a személyi állomány, a létesítmények és berendezések fenntartásával kapcsolatos logisztikai tevékenységek is beletartoznak. Ezen belül most a hulladékkezeléssel kapcsolatos tevékenységekröl ejtünk néhány szót. A Hulladékgazdálkodási törvény, illetve a Hgt.-ben foglaltak betartását segítő rendelkező jogszabályok részletes elöírásokat fogalmaznak meg többek között a hulladékok telephelyen belüli tárolására, pl. üzemi veszélyes hulladéktároló kialakítására (98/2001. (VI.15.) Korm.rend. 3. sz. melléklete), a hulladékok szállítására, mely alapvetően engedélyhez kötött tevékenység, bár a törvény lehetőséget ad a saját hulladék hulladékkezelöhöz történő elszállítására (Hgt. 14. §). A Hgt. 4. sz. melléklete a termelési folyamat egészét meghatározó, a hulladékképződés megelözését szolgáló intézkedéseket fogalmaz meg. Ezek is befolyásolják a vállalkozás logisztikai tevékenységeit, így a logisztika és a hulladékgazdálkodási célok, tevékenységek erőteljesen összefonódnak.

\subsubsection{Hulladékkezelési logisztika a lakosságtól származó hulladékok esetén}

A települési önkormányzat a hulladékgazdálkodási közszolgáltatás ellátását a közszolgáltatóval kötött hulladékgazdálkodási közszolgáltatási szerzödés útján biztosítja (Hgt. 33.§ (1) bek.). A közszolgáltató közszolgáltatási díj ellenében gondoskodik a hulladékgazdálkodási közszolgáltatás biztosításáról, mely során figyelembe veszi a hulladék hierarchia (1. megelőzés, 2. újrahasználat, 3. anyagában történő hasznosítás, 4. energetikai hasznosítás, 5. ártalmatlanítás) érvényesülését. A hulladékok szelektív gyüjtésével elősegíti, illetve biztosítja, hogy az elöirányzott hulladékkezelési arányok teljesüljenek. A Hgt. 78. §-ában elöírt közszolgáltatói hulladékgazdálkodási tervben 3 évre elöre tervet készít. Ebben részletezi, hogy a törvényben meghatározott elöírások teljesülése érdekében a közszolgáltatási területén begyưjötött hulladék kezelése során milyen intézkedéseket kíván tenni, azokat milyen eszközökkel éri el. Azaz, a gazdasági szférában amúgy is jelenlévő 
menedzsment szemlélethez tartozó tervezést a hulladékkezelés területén a törvény is elöírja. A regionális hulladéklerakók üzemeltetése óta a korábban kialakított, jellemzően a lakott település határában található, az uniós elöírásoknak nem megfelelő lerakókat bezárták (jelentős részüket már rekultiválták). Ez a hulladék begyưjtés és szállítás alapvető megváltozását eredményezte, a szállítási távolságok, ezáltal a szállítási, valamint a kezelési, lerakó üzemeltetési költségek megnőttek, mely a szállítási tevékenység teljes átszervezését igényelte. A korábbi gyakorlatra jellemző volt, hogy önkormányzati cégek szállították a hulladékot a település szélén lévő szeméttelepre, ehelyett ma már általában a lerakót uizemeltető gazdasági társaság (a jogszabályi elöírások szerint már többségi önkormányzati tulajdonnal rendelkező közszolgáltató) végzi a hulladék begyüjtését, szállítását. A lakosságtól származó hulladékok szelektív gyüjtését több módon biztosít(hat)ja a közszolgáltató. Ugyanakkor szelektíven csak azokat a hulladékokat tudja begyüjteni, melyet a lakosság szétválogat. A logisztika fogalmának ellátási-lánc menedzsment szerinti meghatározásában fontos szerepet tölt be az anyagok, szolgáltatások mellett az információ áramlása. A hulladékkezelési logisztika ezen pontján, ahol a lakosság és a hulladékkezelő együttmüködésén múlik a siker, nagy jelentösége van annak, hogy a lakossághoz megfelelö mennyiségü és minöségü információ jusson el. Különösen igaz ez akkor, amikor anyagilag a lakosság nincs motiválva a szelektív gyüjtésben, „csak” a környezettudatos hozzáállására épít a közszolgáltató. Bár a Hgt. kimondja, hogy a közszolgálati díjnak a hulladék mennyiségével arányosnak kell lennie, ez nem igazán érvényesül pl. Szegeden. Itt a megfelelő ürtartalmú hulladéktároló edény ürítése után fizet a hulladéktermelö, a szolgáltatási díj a hulladékgyüjtő edény ürtartalmától függ, de nem függ attól, hogy a kukája félig van, esetleg másfélszeres mennyiséggel tömte-e meg. Megoldás a családi házas területeken lenne lehetséges feltétel a saját hulladéktároló edény megléte - a tárolóedények chippel történő ellátása, és ürítés elötti súlymérése és azonosítása mellett. Lakótelepeken ennek megoldása sokkal bonyolultabb a közös gyüjtöedény miatt. Az egyedi tömegmérés esetén a lakos már motivált lenne a keletkező hulladék mennyiség csökkentésében, melyet többek között a szelektív gyüjtéssel érhetne el. Ilyen rendszer már több helyen müködik az országban, és uniós pályázat elnyerése esetén Szegeden is szóba került a megvalósítása. Szintén Szegeden, a családi házas övezetekben, valamint további 13 településen müködik a szelektív hulladékok „sárga zsákos” gyüjtése. A sárga zsákok begyüjtését a rezsicsökkentés után a közszolgáltató átszervezte és a heti begyüjtés helyett azokat kéthetente szállítja el. A begyüjtés gyakoriságának változtatását a költségek csökkentése mellett azzal indokolták, hogy a heti elszállítás esetén sokan csak a félig megtöltött zsákot helyezik ki, mely így a felhasznált zsák fajlagos mennyiségét figyelembe véve (se) gazdaságos. Hódmezővásárhelyen 240 literes gyüjtőedényt biztosítottak a háztartásoknak, melyek fedele sárga, így hívja fel a figyelmet a belehelyezendő papírra és müanyagra. A zöldhulladék - hasonló módon - de barna fedelü edényzetbe kerül. A heti-kétheti elszállítás nem is okoz problémát, kivéve, ha a lakosság elfelejti, hogy melyik héten szállítják el a szelektíven gyüjtött hulladékát, és a nem megfelelö időpontú kihelyezés miatt a sárga zsák vagy edény az utcán marad, mely a lakosnak bosszúságot okozhat és kedvét 
veheti a rendszerben való további részvételtől. A sárga zsákba a lakosok a papír, műanyag és fém hulladékokat helyezhetik el hasznosításra alkalmas tiszta állapotban - üveget a további kezelés balesetveszélye miatt nem lehet a sárga zsákban elhelyezni. Az üvegek szelektív gyüjtése indokolt lenne - hiszen nagyon hosszú lebomlási idejü anyagról van szó - ennek ellenére gyüjtése a leginkább kezdetleges. A vegyes szelektív hulladékot a közszolgáltató a szilárd települési hulladéktól elkülönítve, külön járattal gyüjti be és szállítja a hulladékkezelő telep válogatócsarnokába. Ott a válogatósoron válogatják szét anyagi minőség szerinti frakciókra, mely a hasznosítás alapfeltétele (1. ábra). Utána az egyes hulladékfrakciókat bálázzák, tárolják, majd a megfelelő hulladékhasznosítóhoz szállítják.

\section{1. ábra: Szegedi hulladékkezelő telep válogatócsarnoka}

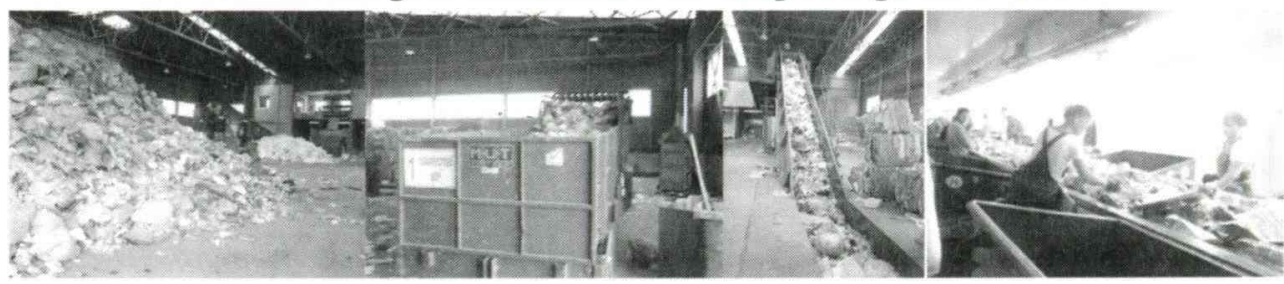

Forrás: https://hu-hu.facebook.com/media/set/?set=a.169269066436815.35582.168304643199924\& type $=3(2016 \cdot 10.12$. $)$

A szelektíven gyüjtött hulladékok mennyiségét jelentősen növelni kell még ahhoz, hogy a jogszabályi elöŕrásoknak megfelelő mennyiség hasznosításra kerülhessen. A jelenleg Szegeden és körzetében működő rendszer kapacitásának korlátok nélküli növelése azonban a válogatómủ véges kapacitása miatt nem lehetséges. A végső megoldás az kellene, hogy legyen, ami sok más országban megbízhatóan múködik: a lakosságnál, azaz a hulladék keletkezésének helyén elvárni és biztosítani a megfelelő szintü válogatást, és már az ingatlantól megtörténhetne a frakciónkénti szelektív elszállítás (2. ábra). A gyüjtő edényt a közszolgáltató biztosítja, és mivel a lakosság szívesen használja ezeket a saját dolgai tárolására is, föleg a rendszer bevezetésekor jelentős volt a pótlási arány. Azóta már a rendszer beállt, inkább csak az elhasználódás miatt szükséges a tárolóedények pótlása. A szegedi közszolgáltató tapasztalatai alapján jelenleg a lakosság hozzáállása még nem megfelelő, a szétválogatás szelektivitása még kívánni valót hagy maga után, ezért mindenképpen utóválogatás szükséges. 


\section{2. ábra: Szelektív hulladék háztól történő begyưjtése Penrithben (Cumbria, Anglia)}

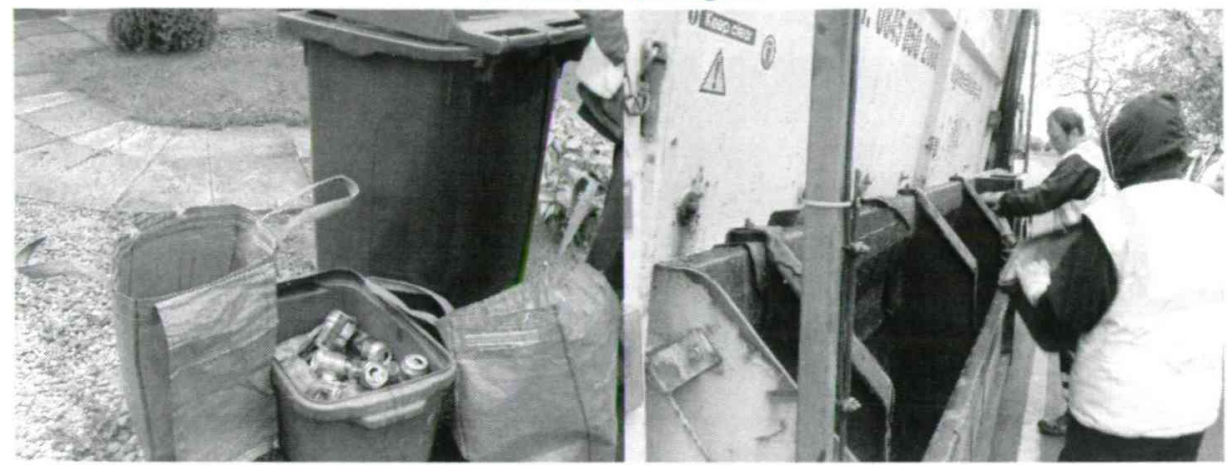

Forrás: Szerzői készítésủ fotó (2016)

Itthon a szelektív hulladékgyüjtés szélesebb tömegek számára a településeken kihelyezett gyűjtőszigeteken érhető el. Itt fém, papír és mủanyag, illetve üveg csomagolási hulladékok szelektív gyüjtésére van lehetőség a kihelyezett edényekben, konténerekben. A gyüjtöszigetekröl - az üveghulladék kivételével - a külön konténerekbe elhelyezett fém, papír és müanyag hulladékokat egy szállítójármü gyüjti be, gyüjtőszigetről gyüjtőszigetre járva, míg a raktér meg nem telik. Ezután viszik a csomagolási hulladékokat szintén a válogatómübe továbbválogatásra. Nagyon sok negatív visszajelzés volt hallható, és jutott el a közszolgáltatóhoz is, hogy miért kell különválogatni az egyes hulladékfajtákat, ha a szállítás során azokat összekeverik. Ez a megoldás nem támogatta a szelektív gyüjtés, a gyüjtőszigetek használatának elterjedését. Ma már annyi változás figyelhető meg, hogy ezekre a hulladékgyújtő gépjármúvekre ráírták, hogy „szelektív hulladék továbbválogatásra”. Számos, de nem minden településen müködik hulladékudvar, mely már jóval szélesebb körủ szelektív gyüjtést tesz lehetővé a lakosság számára, sok esetben olyan hulladékok szelektív gyüjtése is csak itt valósítható meg, mely más hulladékáramban nem gyüjthető (pl. használt festékmaradék, gumi, veszélyes hulladékok). Vannak olyan hulladék típusok, melyek - a hulladékudvarokon kívül - a kereskedelem hagyományos ellátó láncával ellentétes áramlási irányban, a boltokban kihelyezett gyűjtőedényeken keresztül is visszajuttathatók a forgalmazónak, gyártónak, ilyenek pl. az elem, akkumulátor hulladékok, fénycsövek, elektronikai hulladékok, gyógyszerek. Ezek a gyüjtőpontok közelebb vannak a lakossághoz, így ezek elfogadottsága, kihasználtsága jónak tekinthető. A közszolgáltató a lakosok ingatlanától szállítja el a vegyes települési hulladékot, mely a hulladéklerakón ártalmatlanításra kerül. A zöld hulladékok háztól való elszállítása csak Szegeden működik, a környező településeken, melyek szintén a közszolgáltató ellátási területéhez tartoznak, nem elérhető. Évente egyszer, vagy kétszer szervez a közszolgáltató lomtalanítást, mely az előre bejelentett időpont miatt a szegényebb népcsoportok számára nagy beszerzések végrehajtását teszi lehetővé, és bár a lomizást a törvény tiltja, a közszolgáltató már csak a szétdobált, kiválogatott maradékot tudja begyüjteni. A lomtalanítást követő áldatlan állapotok megszüntetése 
érdekében tervezik bevezetni, hogy igény szerint a lakos által kért idöpontban vinnék el a feleslegessé vált holmikat. A felesleges, de használható tárgyak kezelésére jó megoldás a még nem müködö, de törvényi szinten támogatott, a hulladékudvarokhoz hasonló újrahasználati központok kialakítása, müködtetése. A szegedi közszolgáltató tevékenységére vonatkozó föbb adatokat (a teljesség igénye nélkül) az alábbi táblázat tartalmazza (1. táblázat).

\section{1. táblázat: A Szegedi Környezetgazdálkodási Nonprofit Kft. hulladékszállítási közszolgáltatási tevékenységének fỏbb mutatószámai}

\begin{tabular}{|c|c|}
\hline Ellátott feladat & Ellátási körzet \\
\hline $\begin{array}{l}\text { Regionális települési szilárd hulladékszállítási } \\
\text { közszolgáltatás }\end{array}$ & 14 település \\
\hline Szelektív hulladékgyüjtési és szállítási közszolgáltatás & \\
\hline \begin{tabular}{l|l} 
gyüjtőszigetek \\
\end{tabular} & 32 település \\
\hline hulladékudvarok & 28 település \\
\hline sárga zsákos hulladékgyüjtés & 14 település \\
\hline színtelen és big-bag zsákos zöldhulladék gyüjtés & $\begin{array}{l}1 \text { település } \\
\text { (Szeged) }\end{array}$ \\
\hline Lomtalanítási közszolgáltatás & 14 település \\
\hline Konténeres hulladékszállítási közszolgáltatás & 14 település \\
\hline $\begin{array}{l}\text { Mobil szelektív hulladék gyūjtőpontokon begyủjtött } \\
\text { hulladék elszállítása }\end{array}$ & 33 település \\
\hline Elhagyott hulladék elszállítása & 14 település \\
\hline Ellatáshoz rendelkezésre álló szállitójármïvek & mennyisége $/ \mathrm{db}$ \\
\hline konténeres gépjármü & 28 \\
\hline platós gépjármü & 8 \\
\hline tömörítös hulladékszállítási gépjármü & 30 \\
\hline végfalas gépjármú & 2 \\
\hline
\end{tabular}

Forrás: http://www.szkht.hu/images/files/Kozszolgaltatoi_hulladekgazdalkodasi_terv.pdf (2016.09.30.)

A fent leírtak és a táblázatban szereplő adatok alapján látható, hogy a települési hulladékok begyüjtése, szállítása, kezelése milyen szerteágazó, mind a feladatok fajtáit, mind a begyüjtési, szállítási körzetet tekintve. Ahhoz, hogy a jogszabályi elöírásoknak, az önkormányzati és lakossági elvárásoknak megfelelö, a környezetet kímélö, gazdaságos tevékenységet tudjanak végezni, a logisztikai tevékenységek széles skáláját kell összehangolni

\section{3. Összefoglalás}

A logisztikai tevékenységek és a környezetvédelem, hulladékgazdálkodás kapcsolódási pontjait áttekintve megállapítottuk, hogy bár a logisztikai tevékenységek közül a csomagolás és a szállítás jelentős környezetterhelést jelent, a hulladékkezelési logisztikai tevékenységek célja és feladata a környezet védelme. A 
hulladék termelőjétől, fajtájától fuiggően az egyes logisztikai tevékenységek aránya, jelentősége eltérő. A mezőgazdasági / ipari hulladékok termelője a sok jogszabályi elöírás mellett és ellenére jelentős befolyással bír a tevékenysége során keletkező hulladékok mennyiségére, további kezelésére. A települési hulladékok esetén a lakosság rálátása, befolyása a hulladékok kezelésére kisebb, ugyanakkor nagyon fontos a megfelelö információ átadása, és a szelektív hulladékgyüjtésben való részvétel motiválása.

\section{Irodalomjegyzék}

Barótfi I. (2000):Környezettechnika. Mezőgazda Kiadó. <http://www.tankonyvtar.hu/hu/tartalom/tkt/ kornyezettechnika-eloszo/ch06s05.html> (2016. 05.29.)

Hgt.: azaz a Hulladékról szóló 2012. évi CLXXXV. törvény <http://net.jogtar.hu/jr/gen/ hjegy_doc.cgi?docid=A1200185.TV> (20017.05.20.)

Kovács Z., Pató Gné. Szücs B. (2008):Logisztikai tevékenységek. Nemzeti Szakképzési és Felnöttképzési Intézet, Budapest.

Mosonyiné Ádám G. (2008): Inverz logisztika láncok múködése és optimalizálási szintjei. EU workingpapers 1/2008. <http://elib.kkf.hu/ewp_08/2008_1_11.pdf>117-129., (2016.04.28.)

Némon Z., Sebestyén L., Vörösmarty Gy. (2006):Logisztika. Folyamatok az ellátási lánćban. Kereskedelmi és Idegenforgalmi Továbbképzö Kft., Budapest. 357-361. 